\title{
The Spatiotemporal Analysis of Dengue Fever in Purwosari District, Gunungkidul Regency, Indonesia
}

\author{
Indra Agus Riyantoㄹ, Noor Alia Susianti ${ }^{2}$, Ratri Abdatush Sholihah ${ }^{3}$, Raden Ludhang Pradipta \\ Rizki $^{4}$, Ahmad Cahyadi ${ }^{5}$, Muhammad Naufal, Fajri Ramadhan ${ }^{5}$, Victor Kusuma Ramadan ${ }^{5}$ and \\ Awanda Sistia Risky ${ }^{5}$ \\ ${ }^{1}$ Master Program on Planning and Management of Coastal Area and Watershed Faculty of Geography \\ Universitas Gadjah Mada, Indonesia. ${ }^{2}$ Medical Doctor, Faculty of Medicine Public Health and Nursing, \\ Universitas Gadjah Mada Yogyakarta, Indonesia. ${ }^{3}$ Master Program of the Department of Computer \\ Science and Information Engineering National Central University Taiwan. ${ }^{4}$ Department of Microbiology \\ Faculty of Medicine, Public Health and Nursing, Universitas Gadjah Mada Yogyakarta, Indonesia. \\ ${ }^{5}$ Department of Environmental Geography Faculty of Geography Universitas Gadjah Mada Yogyakarta, \\ Indonesia.
}

Received: 2019-10-11 Accepted: 2020-02-26

Key words:

Dengue Fever;

GIS Analysis;

Physical Geography;

Preventive Behavior-

Endemicity.

Correspondent email:

ahmadcahyadi@geo.ugm.ac.id

\begin{abstract}
From 2014 to 2016, the number of prevalence of Dengue Hemorrhagic Fever (DHF) and deaths associated with DHF in Indonesia increased. DHF fatal cases were also reported from three administrative units in the Special Region of Yogyakarta, namely Bantul Regency, Gunungkidul Regency, and Yogyakarta City. Two related deaths in Purwosari, a district in Gunungkidul, raised the status of DHF to an outbreak. This study was designed to characterize the spread pattern of DHF in its endemic areas in Purwosari District using the retrospective method, anamnesis, in-depth interviews, Geographic Information System (GIS), and environmental analysis. The kernel density estimation revealed that in 2011-2017, DHF was concentrated in four villages, namely Giriasih, Giricahyo, Giritirto, and Giripurwo. There was a correlation between DHF incidents and physical geographical features of these villages, including proximity to water sources, high vegetation density, elevation, humidity, and rainfall, which created habitats for mosquito growth. A high incidence of DHF has been observed in children (50.8\%) and students (57.4\%), with most cases (78.7\%) showing typical symptoms of the disease. A few of the 61 cases in the district developed into dengue shock syndrome (DSS) and led to death (4.9\%), mainly because the public was unable to recognize the warning signs of DHF early and had limited knowledge of required management therapy. Moreover, the preventive or precautionary measures known as the $3 \mathrm{M}$-Plus were not fully implemented yet.
\end{abstract}

\section{Introduction}

In the last 50 years, there has been a 30 -fold increase in cases of dengue fever, reaching up to 50 million patients each year. Around $70 \%$ of the population in the Asia Pacific, especially in developing countries such as the Philippines, Indonesia, Vietnam, and Thailand, are at risk of dengue fever (Duncombe et al., 2012). In Indonesia, 100,347 cases of dengue hemorrhagic fever (DHF) and 907 related fatalities were reported in 2014. This figure increased to 129,650 cases that resulted in 1,071 deaths in 2015 and to 202,314 cases with 1,593 deaths in 2016 (Departemen Kesehatan RI, 2018).

In the Special Region of Yogyakarta, paying closer attention to the occurrence of DHF throughout the year is essential as it is endemic in the region (Dinas Kesehatan Pemerintah Kota Yogyakarta, 2015). In 2016, 6,247 cases were reported with 26 deaths or a fatality rate of $0.42 \%$. Meanwhile, back in 2011, there were records of DHF-related deaths in three administrative units in the region, including Bantul Regency, Gunungkidul Regency, and Yogyakarta City (Dinas Kesehatan Provinsi D.I. Yogyakarta, 2012).

As publicized in the Gunungkidul Health Service report, there was no record of DHF cases in Purwosari, a district in Gunungkidul Regency, in 2011. However, it changed as two cases of DHF led to one fatality in 2012, marking the start of an outbreak in the district. Afterward, the incidents of DHF continued to occur in Purwosari District at least until the latest official report in 2017.

DHF outbreaks are associated with various risk factors, namely (1) suitable environment for the breeding site of Ae- 
des mosquito, (2) low public awareness of eradication of mosquito nests through the preventive measures known as 3M-Plus, (3) expansion of endemic areas because environmental changes and modifications intensify with urbanization and the construction of new residential areas, and (4) increased population mobility (Kementerian Kesehatan Republik Indonesia, 2016). In 2016, up to 20,713 people lived in Purwosari District where a high intensity of in- and outmigration takes place. At the same time, densely vegetated land received high rainfall during the rainy season. These factors preconditioned the DHF outbreaks in Purwosari District.

Geographic Information System (GIS) will help identify the spread pattern of DHF in the study area. Endemicity and spread pattern are attributable to surface water conditions and climatic factors, which are temperature, rainfall, humidity, and wind (Soegijanto, 2004). A physical environmental analysis can determine the environmental risk factors of DHF outburst. Based on the DHF case report acquired from the Office of Health Service and community health center, the extent and direction to which DHF spreads need to be mapped. This paper characterizes the distribution patterns based on physical environments, risk factors, and community habits against dengue fever in 2011-2017, as observed from the applied precautionary and promotive efforts and early detections to break the chain of DHF endemicity and mortality in Purwosari.

\section{The Methods}

This observational and descriptive research employed several methods: (1) retrospective approach to search for any DHF incidence in Purwosari District in 2011-2017 through the case reports issued by the Office of Gunungkidul Health Service and the district's healthcare center, (2) anamnesis and in-depth interview to obtain demographic data of patients, clinical details, and community behavior toward DHF, (3) spatiotemporal analysis using GIS to identify DHF distribution from 2011 through 2017, and (4) physical analysis to process data of rainfall, temperature, humidity, elevation, vegetation density, and proximity to water sources that were obtained from field observations and secondary data analysis.

For the interview, the respondents were determined from a census of DHF patients. The main observed parameters during the in-depth interview were (1) demographic data (i.e., age, sex, education level, occupation, and marital status), (2) clinical data (i.e., clinical symptoms, place of care, time-lapse between the fever onset and the start of treatment, length of hospital stay, diagnosis, patient outcomes, and laboratory examination results, (3) DHF-preventive behavior, (4) transmigration patterns of DHF patients and the people in their surroundings, and (5) the number of water reservoirs with or without apparent mosquito larvae. These data were recorded in a questionnaire and then analyzed by descriptive methods.

The GIS analysis was spatiotemporal and used a timeseries map of yearly cases of dengue fever to determine the distribution patterns of the disease. In addition to annual distribution, the analysis also utilized the spatial analysis tools, namely kernel density. This feature estimated the trend of DHF cases based on their density (Davies et al., 2011; Shi et al., 2013; Aziz et al., 2014). GIS-based analysis and processing were executed in ArcGIS 10.3. The locations of the DHF patients were recorded during the field survey using a Global Positioning System (GPS).

The environmental analysis emphasized on the relationship between the living requirements of mosquitoes and the physical conditions in the district, including climate (temperature and humidity), geomorphology (elevation), vegetation density, and distance from house to water sources (ponds, river, and springs). The secondary climatic data were temperature, humidity, and rainfall in the last five years; all of which were interpolated with different geostatistical analysis tools, and the selected interpolation technique was the one producing the smallest RMS error (Ohmer et al., 2017). The geomorphological analysis processed elevation data extracted from the Digital Elevation Model (DEM). As for the vegetation density, the investigation was based on field observations (qualitative) and satellite imagery (quantitative). The environmental and GIS analyses were carried out descriptively and correlated with the living requirements of the carrier mosquitos and the location of DHF incidents. In this study, the relationship between dengue fever prevalance and environmental factor is analized using SaTSCan v9.6. The result will show the dengue distribution is clusterly or randomly distributed (Coleman et al., 2009).

Purwosari District is located in Gunungkidul Regency, part of the Special Region of Yogyakarta, Indonesia (Figure 1). It lies between $110^{\circ} 20^{\prime} 00^{\prime \prime}-110^{\circ} 25^{\prime} 00^{\prime \prime} \mathrm{E}$ and $7^{\circ} 58^{\prime} 30^{\prime \prime}-8^{\circ}$ 4'30"S and covers an area of $67.97 \mathrm{~km}^{2}$ with five villages, namely Girijati, Giricahyo, Giriasih, Giritirto, and Giripurwo. This district has a population of 20,713 people, with a density of 2.73 people per ha (BPS Kabupaten Gunungkidul, 2017). Generally, it receives $2300-2400 \mathrm{~mm}$ of rainfall per year (Brunsch et al., 2011) and has an average temperature of $27^{\circ} \mathrm{C}$ (Haryono and Day, 2004).

Purwosari District lies in a karst region designated as the Gunungsewu Geopark (Haryono and Suratman, 2010) with morphological slopes varying between 15 and $20^{\circ}$. The land area is mostly used for dry agricultural practices $(5,403.35$ ha), whereas only small parts of it are utilized as rice field (180.30 ha), forest (319.76 ha), and settlement (466.81 ha) (BPS Kabupaten Gunungkidul, 2017). 


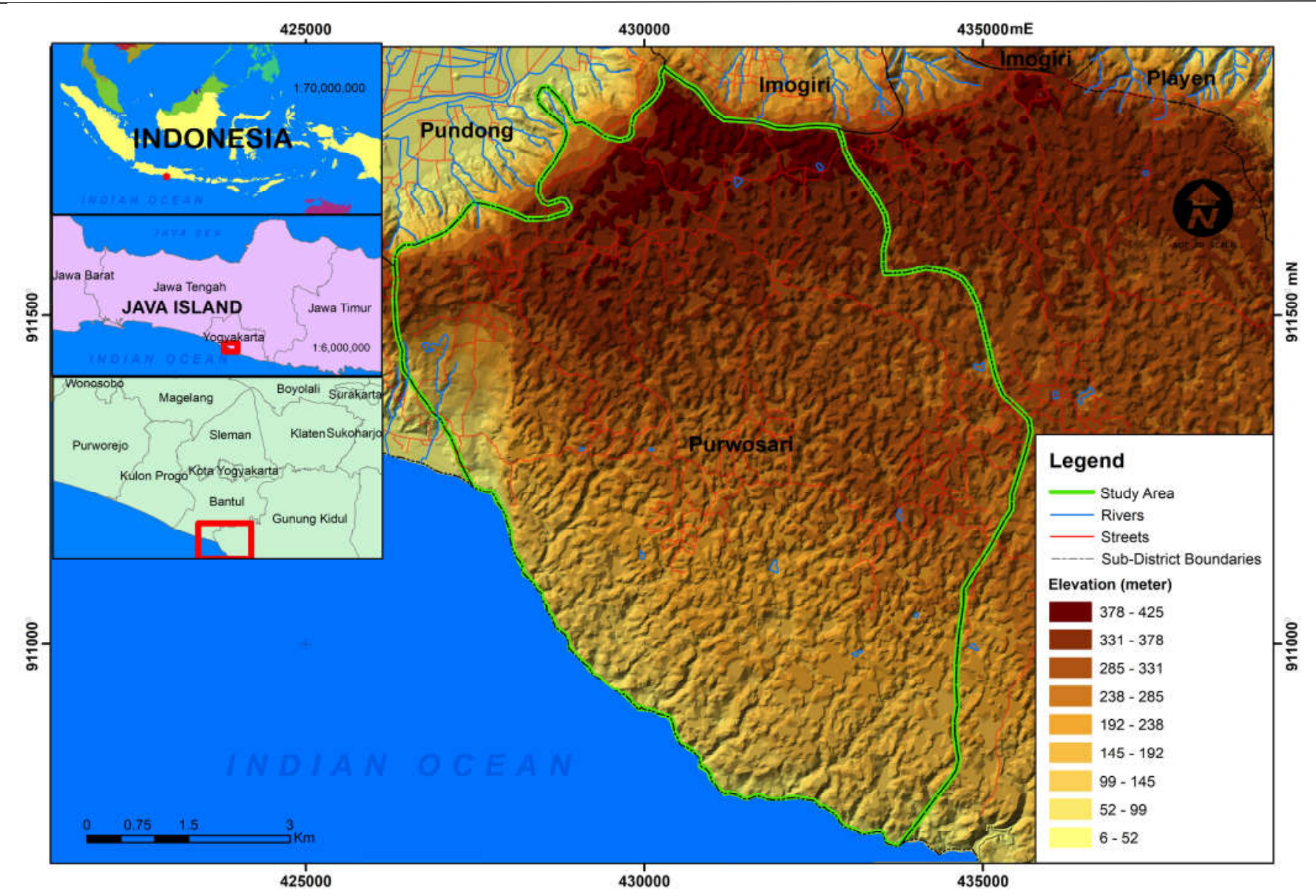

Figure 1. The map of the study area

\section{Results and Discussion}

The surveillance of DHF from 2011 to 2018 revealed that there were 61 cases in five villages, namely Girijati, Giricahyo, Giriasih, Giritirto, and Giripurwo. The highest incidence, i.e., 21 cases, occurred in 2013, with Giritirto Village having the most considerable number of DHF cases in 2011-2017 (Figure 2). The kernel density estimation generated the spatiotemporal distribution and repetition patterns of DHF incidence in the study area, as presented in Figure 3. DHF was found to primarily cluster in four villages, namely Giriasih, Giricahyo, Giritirto, and Giripurwo.

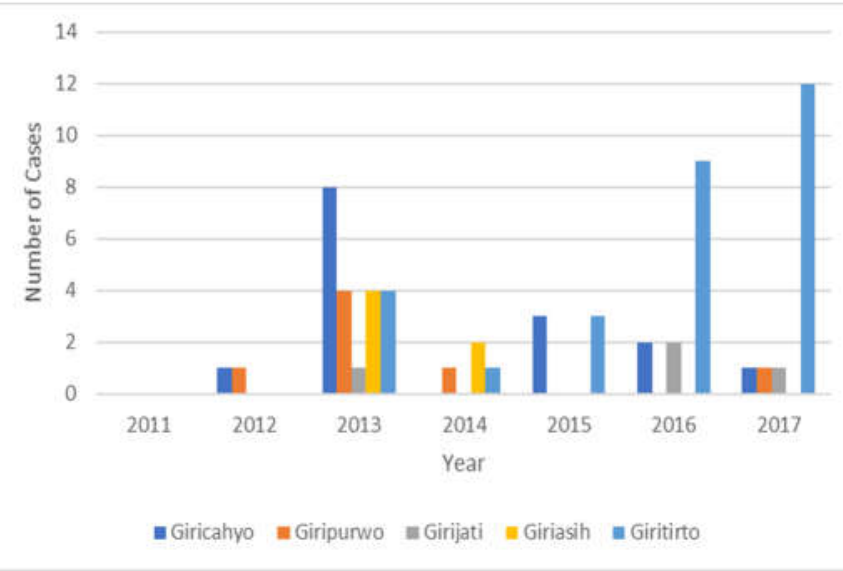

Figure 2. The number of dengue hemorrhagic fever (DHF) cases in Purwosari District, Gunungkidul Regency, the Special Region of Yogyakarta in 2011-2017

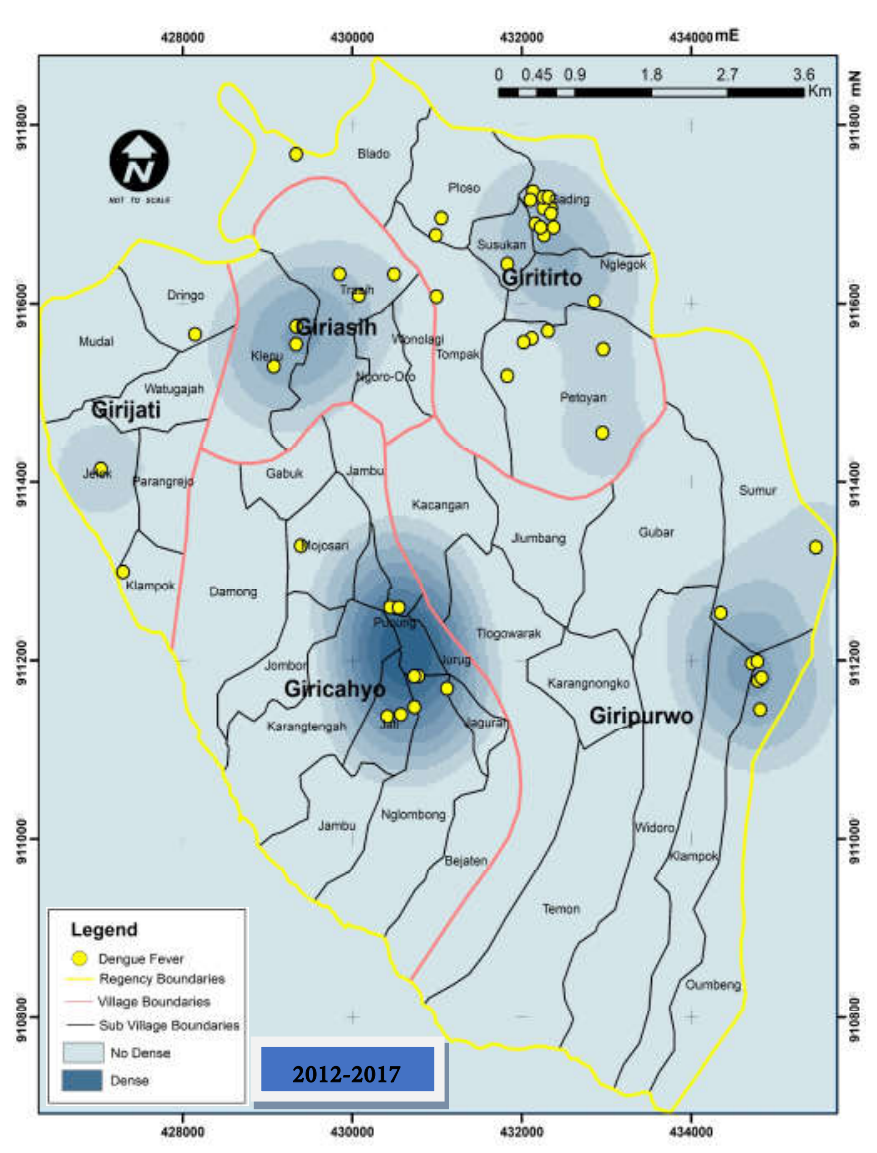

Figure 3. The maps of dengue hemorrhagic fever (DHF) incidents produced by kernel density estimation in Purwosari District in 2011-2017 
A more detailed analysis at the sub-village level showed that the incidence was centered at Trasih and Klepu Hamlets (parts of Giriasih Village), Jambu, Jati, and Nglombong Hamlets (Giricahyo Village), and Gading, Ploso, and Petoyan Hamlets (Giritirto Village). The GIS-based analysis provides information on the DHF distribution patterns and deduces the endemic regions (Chu et al., 2013; Castillo et al., 2011; Panthwer et al., 2017).

The second step in the physical environmental analysis attempted to identify whether the geographical features were suitable for the life cycle of DHF-carrier mosquitos. The parameters included elevation, rainfall, humidity, temperature, distance to water sources, and vegetation density. The elevation data was analyzed from the Digital Elevation Model (DEM) of Purwososari District, which is located at 150-400 m a.s.l. (Figure 4-left). Giritirto, Giriasih, and Girijati have varying elevations from 280 to $400 \mathrm{~m}$, while Giricahyo and Giripurwo are situated on lower terrains between 61-280 m. These elevations are suitable for the living and breeding conditions of DHF-carrier mosquitoes, i.e., 0-1700 m (LozanoFuentes et al., 2012; Gama et al., 2013; Moreno-Madrinan et al., 2014). Accordingly, more occurrences dengue fever were reported from higher altitudes in the district. Giritirto has the highest elevation and, at the same time, the most significant number of DHF (29 cases), indicating a correlation between elevation and DHF incidents.

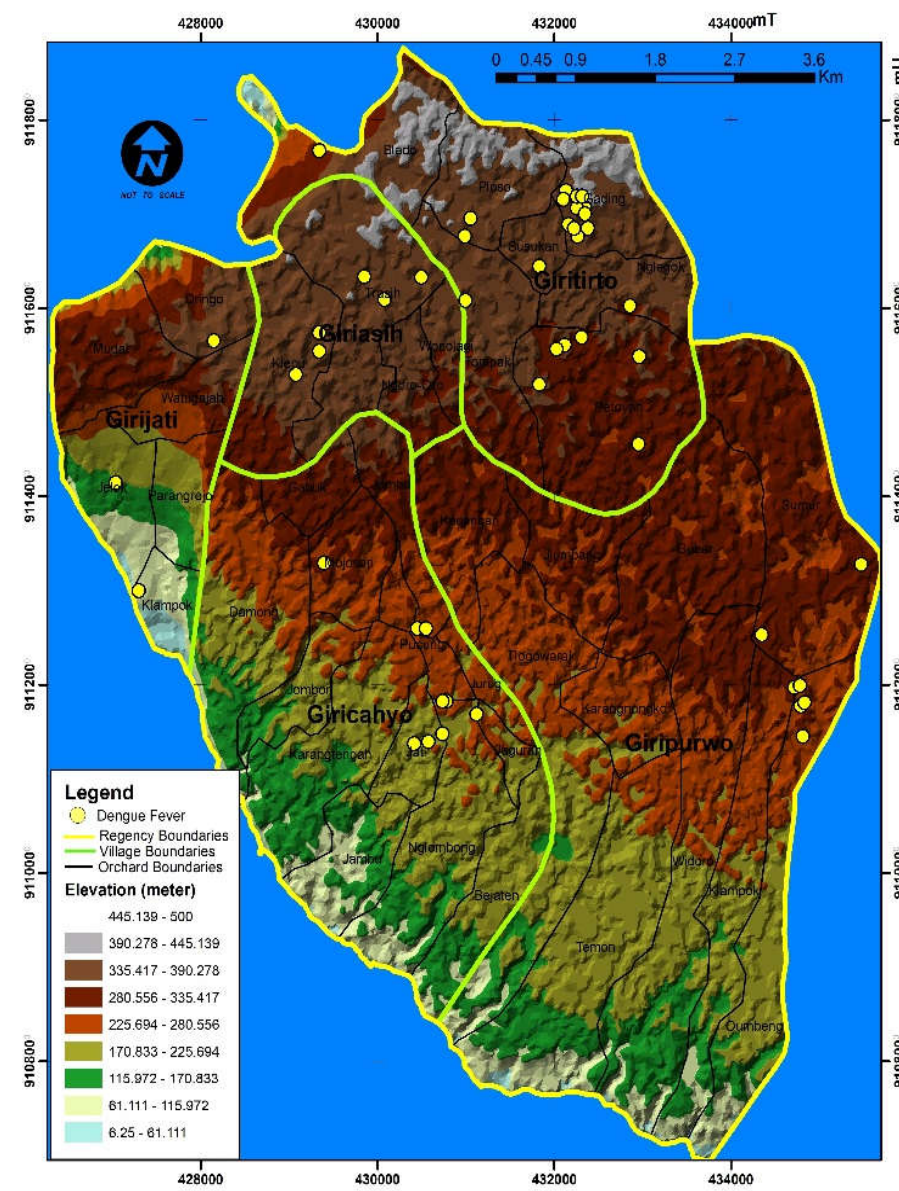

Figure 4. The elevation (left) and temperature (right) distribution in Purwosari District
The temperature analysis from the records of the meteorological stations showed that the temperature of the district ranged from 26 to $28^{\circ} \mathrm{C}$ (Figure 4-right). Girijati, Giriasih, Giritirto, Giricahyo, and part of Giripurwo had an average temperature of $27-28^{\circ} \mathrm{C}$, while the other part of Giripurwo had an average temperature of $26-27^{\circ} \mathrm{C}$. This range of temperature meets the living and breeding conditions of DHFcarrier mosquitoes, that is, $20-30^{\circ} \mathrm{C}$ (Gomes et al., 2012; Ehelepola et al., 2015; Jemal and Al-Thukair, 2016). An environment with lower or higher temperatures than this classification can inhibit the growth and multiplication of the carrier mosquitoes.

The rainfall analysis used a five-year data and found that the regional rainfall of Purwosari District was approximately 2000-2200 mm/year (Figure 5-left). The rainfall distribution was divided into two zones, namely (1) 2,100-2,200 mm/year of rainfall that covered Girijati, Giriasih, Giricahyo, part of Giritirto, and part of Giripurwo and (2) 2,000-2,100 mm/ year of rainfall in the other parts of Giritirto and Giripurwo. With this amount of rain, the physical condition of the district allows DHF-carrier mosquitoes to multiply and grow. The larvae, pupae, and mosquitoes that carry and transmit DHF thrive in tropical regions with an average rainfall of 2000-3000 mm/year (Paul and Tham, 2015; Edirisinghe, 2017; Chanprasopchai et al., 2017). Rainfall positively correlates with humidity. The analysis results showed that more cases of DHF were reported from areas receiving higher annual rainfall.

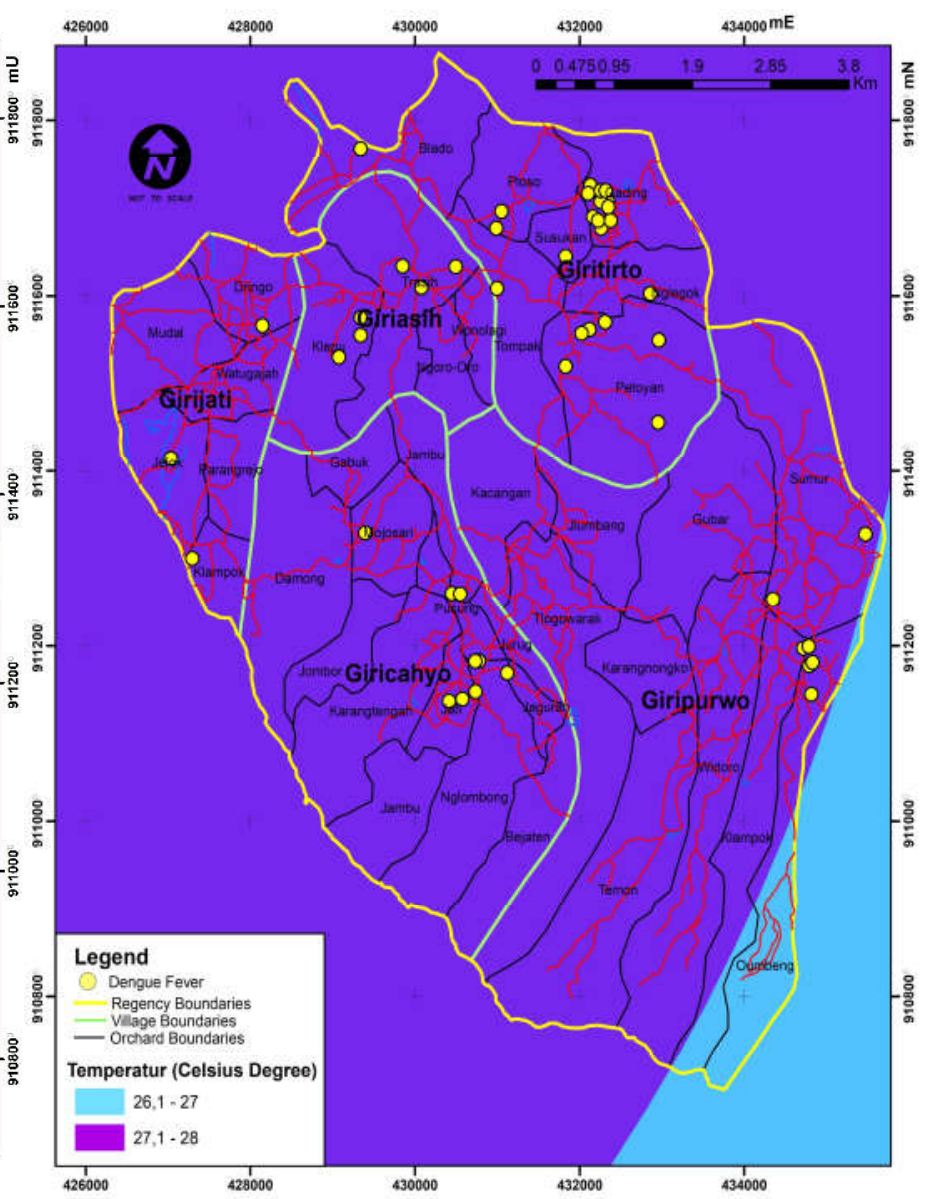



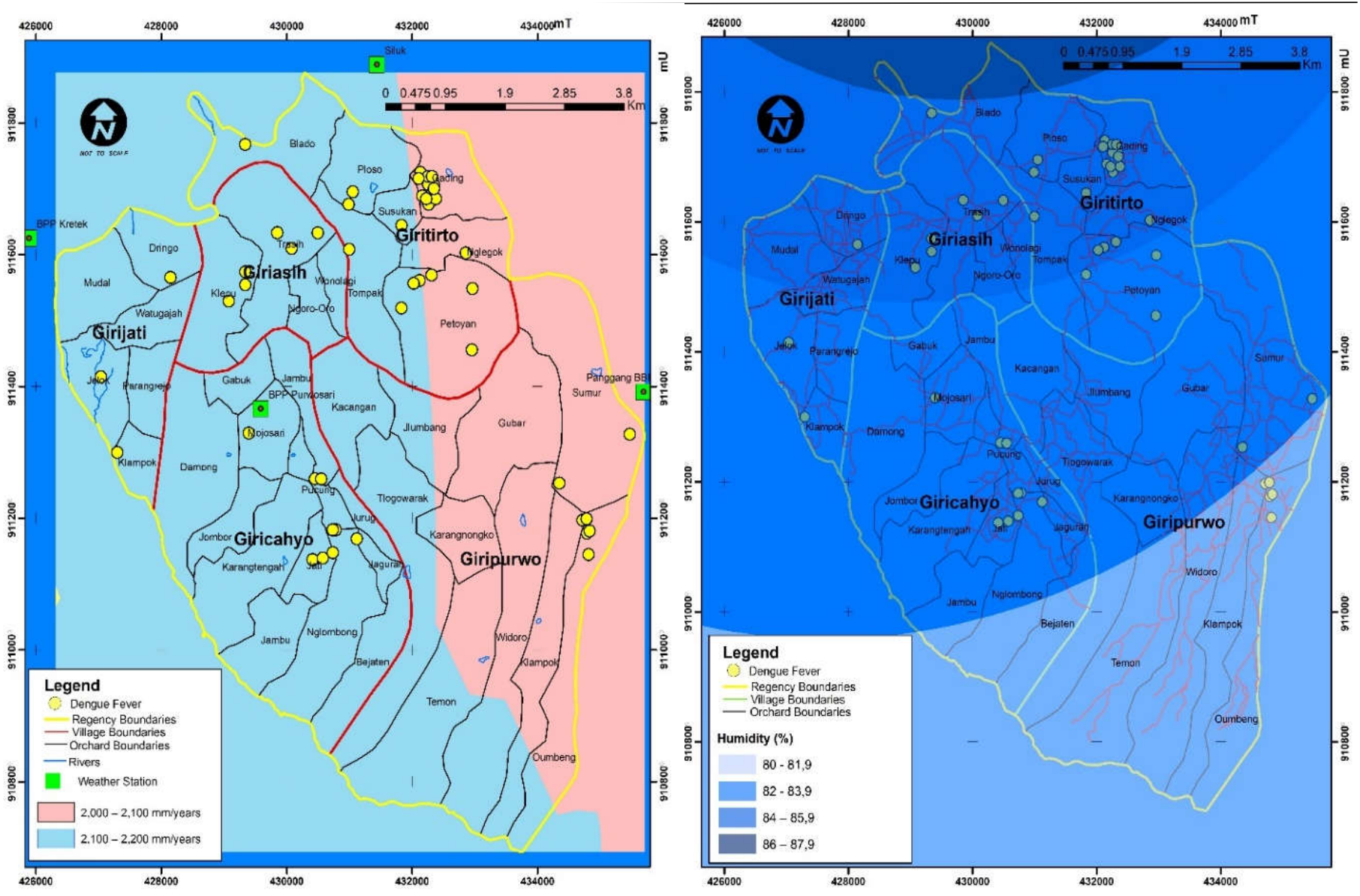

Figure 5. The rainfall (left) and humidity (right) distribution in Purwosari District

The meteorological station also gauges humidity, and the analysis results showed that the humidity of the district ranged from 80 to $87 \%$ (Figure 5-right). The humidity of Girijati, Giriasih, and Giritirto was $85-87 \%$, while that of Giricahyo and Giripurwo was $80-85 \%$. At this range, the entire district is the right place for DHF-carrier mosquitoes to grow, that is, 60-90\% (Al-Ghamdi et al., 2009; Gu et al., 2016; Ruzman and Rahman, 2017). The higher the humidity, the better the growth and the longer the life span of these mosquitoes are. As a conclusion, the cases of DHF in Purwosari District increase with humidity.

Based on the buffer analysis results, the distance from home to water sources correlated with the incidents of DHF. The $400 \mathrm{~m}$ and $1000 \mathrm{~m}$ buffers from rivers, ponds, and springs indicated that nearly all cases of DHF in Girijati, Giricahyo, Giritirto, and Giripurwo were within the buffer areas (Figure 6-left). The abundance of surface water provides potential areas for DHF-carrier mosquitoes to breed and spread (Cheong et al., 2014; Tiong et al., 2015; Dom et al., 2016). Moreover, the buffer analysis is useful to determine the movement of these mosquitoes. These mosquitoes can move at least $200 \mathrm{~m}$ and up to $1000 \mathrm{~m}$ (Tsuda et al., 2001; HonÓrio et al., 2013; Alshehri, 2013) depending on the direction of the wind. Several DHF incidents in the district took place outside the generated buffers, namely in Giriasih and Giritirto Village. It is potentially the result of the in-migration of infected patients from outside the region (Table 3 ).
Based on the satellite imagery, all villages in the district have high vegetation density (Figure 7-left), and the land is dominantly used for plantations and dry agricultural fields (Figure 7-right). Field survey on several samples of vegetation density (Girijati and Giricahyo Village) proved that the residential areas infected by DHF were adjacent to thickly vegetated plantations (Figure 7-right). Because the entire Purwosari District has dense vegetation, it creates suitable living and breeding areas for the carrier mosquitoes. Dry agricultural fields and multiple-species plantations are habitats where mosquitoes can lay their eggs and forage from plant nectars (Sarfraz et al., 2012; Cheong et al., 2014; Tiong et al., 2015). There is a correlation between vegetation density, land use, and DHF incidents in Purwosari District.

The analysis results indicate that environmental factors create an endemic area of DHF. The most influencing factors are temperature, rainfall, temperature, elevation, and proximity to water sources (springs, rivers, and ponds), which cannot be treated nor changed. Any environmental shifts can only occur over a geological timescale, except for climate change that alters temperature, humidity, and rainfall patterns (Hugget, 2011; Boyce \& Lee, 2017; Sur et al., 2010).

The analysis showed that clustered patterns are distributed in north, centre, and south area (Figure 8). In north area, the occurance is centered in Giritirto, center of Giriasih, south of Giripurwo and Giricahyo (Table 1). The patterns are consenstrated in those regions because the 

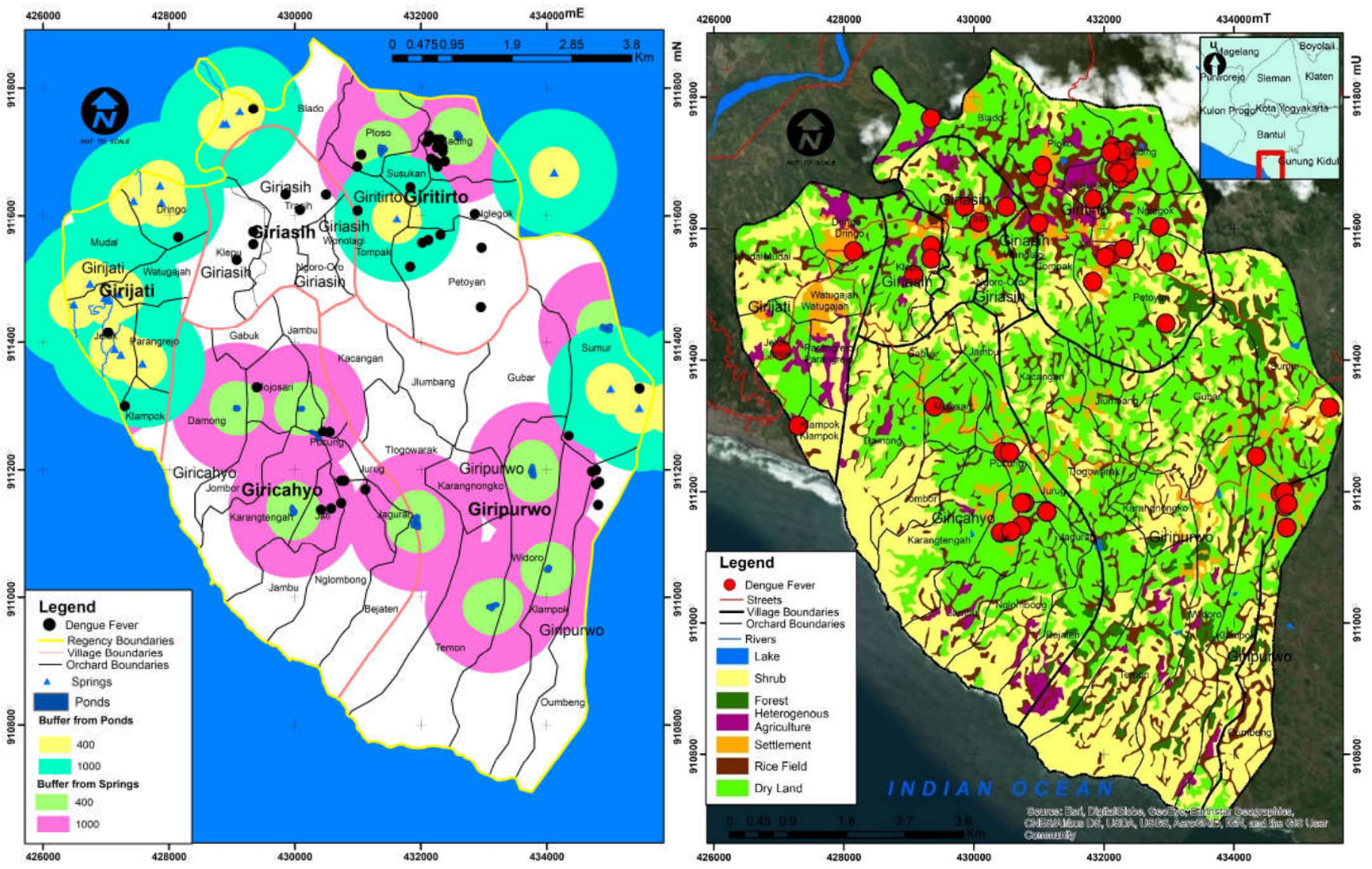

Figure 6. Buffer areas from springs and ponds (left) and the land use (right) in Purwosari District

Table 1. Autocorrelation of Dengue Fever in Purwosari

\begin{tabular}{ccc}
\hline Years & Clustered & Random \\
\hline 2012 & 1 & 1 \\
2013 & 19 & 2 \\
2014 & 3 & 1 \\
2015 & 4 & 2 \\
2016 & 5 & 8 \\
2017 & 9 & 6 \\
\hline
\end{tabular}

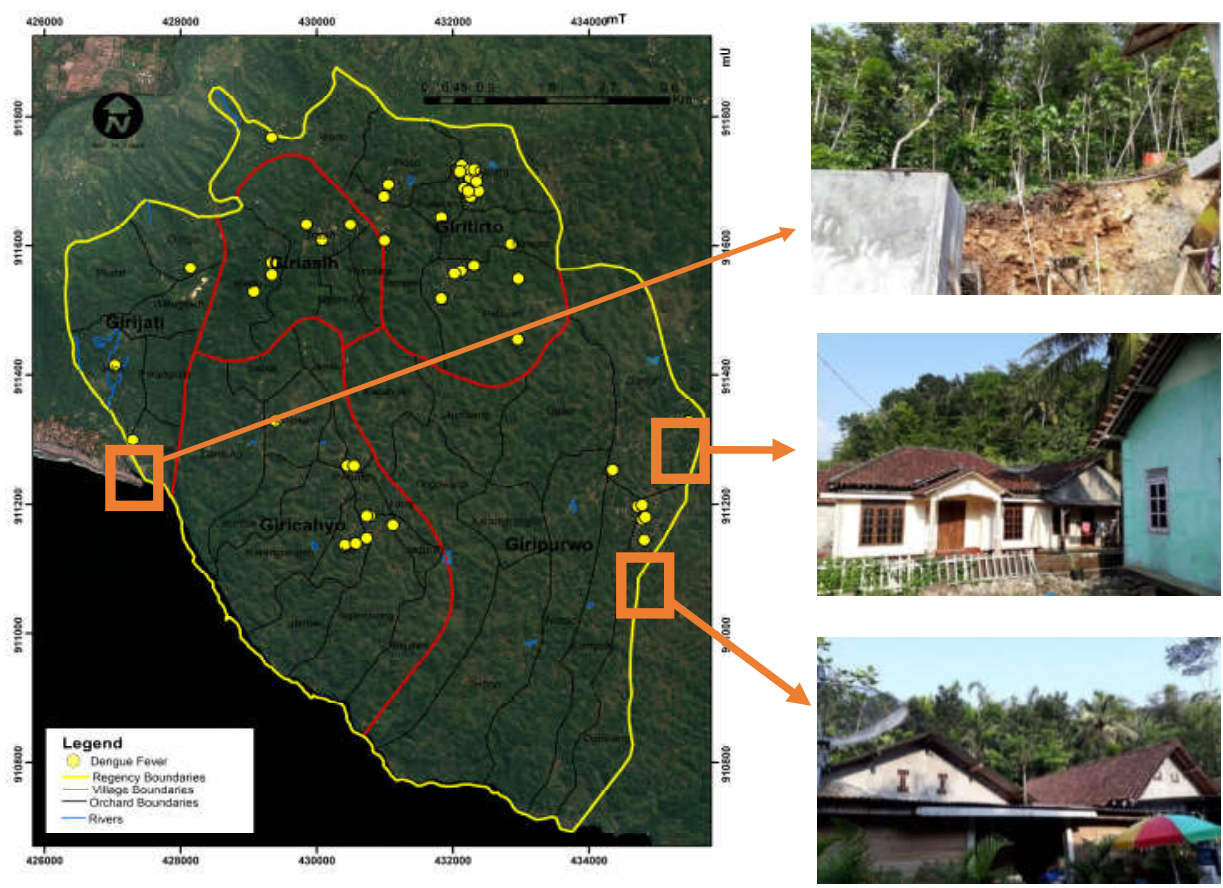

Figure 7. The SPOT image of Purwosari District (left) and pictures taken during the field survey of vegetation density (right) 


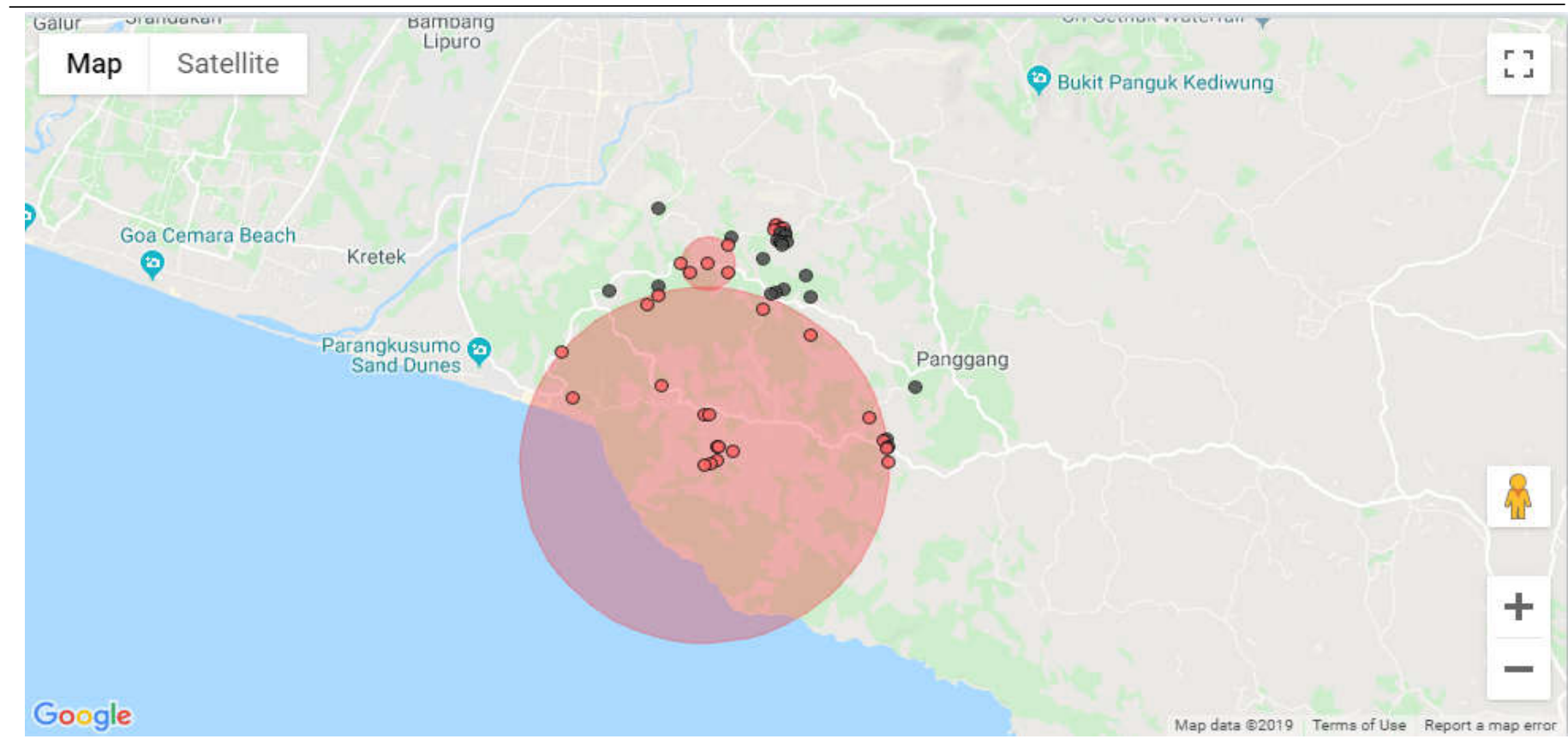

Figure 8. The clustered and random dengue distribution in Purwosari

Table 2. The demographic characteristics of DHF patients in Purwosari District, Gunungkidul Regency, the Special Region of Yogyakarta in 2011-2017

\begin{tabular}{lrrrrrrrr}
\hline Demographic Characteristics & 2011 & 2012 & 2013 & 2014 & 2015 & 2016 & 2017 & Total \\
\hline Sex & 0 & 1 & 14 & 1 & 3 & 5 & 6 & $30(49.0 \%)$ \\
Female & 0 & 1 & 7 & 3 & 3 & 8 & 9 & $31(51.0 \%)$ \\
Male & & & & & & & & \\
Age & 0 & 0 & 13 & 2 & 3 & 6 & 7 & $31(50.8 \%)$ \\
Children & 0 & 1 & 6 & 2 & 3 & 6 & 5 & $23(37.7 \%)$ \\
Adolescents & 0 & 0 & 2 & 0 & 0 & 0 & 2 & $4(6.6 \%)$ \\
Adults & 0 & 1 & 0 & 0 & 0 & 1 & 1 & $3(4.9 \%)$ \\
Elderly & & & & & & & & \\
Occupation & 0 & 1 & 4 & 1 & 1 & 4 & 3 & $14(23.0 \%)$ \\
Unemployed & 0 & 0 & 13 & 3 & 4 & 7 & 8 & $35(57.4 \%)$ \\
Students & 0 & 1 & 0 & 0 & 0 & 1 & 3 & $5(8.2 \%)$ \\
Farmers & 0 & 0 & 4 & 0 & 0 & 0 & 0 & $4(6.5 \%)$ \\
Employees & 0 & 0 & 0 & 0 & 1 & 1 & 1 & $3(4.9 \%)$ \\
No Data & & & & & & & & \\
Marital Status & 0 & 1 & 1 & 0 & 0 & 4 & 5 & $11(18.0 \%)$ \\
Married & 0 & 1 & 20 & 4 & 6 & 9 & 10 & $50(82 \%)$ \\
Not Married & & & & & & & & \\
Educational Level & 0 & 1 & 9 & 2 & 3 & 10 & 9 & $34(55.7 \%)$ \\
Elementary School & 0 & 0 & 3 & 0 & 1 & 0 & 2 & $6(9.8 \%)$ \\
Junior High School & 0 & 1 & 2 & 1 & 1 & 2 & 2 & $9(14.8 \%)$ \\
Senior High School & 0 & 0 & 1 & 0 & 1 & 1 & 0 & $3(24.2)$ \\
Higher Education & 0 & 0 & 6 & 1 & 0 & 0 & 1 & $8(13.1 \%)$ \\
Do not attend school & 0 & 0 & 0 & 0 & 0 & 0 & 1 & $1(1.6 \%)$ \\
No Data & & & & & & & & \\
& & & & & & &
\end{tabular}

settlements also consentrate in karst area and near the water sources (lake and springs). In other hand, the random patterned is created because the settlements in those area are randomly distributed but still near the water sources. The settlements have dense vegetation, temperature, rain fall, humidity which are suitable dan support the breeding process of Aedes aegepty. The result show that environmental factors are contributed to dengue fever endemicity, this condition is strengthen by the wide range of the clustered dengue occurance (Rejeki et al., 2019).

The characteristics of DHF patients support the results of GIS-based and environmental factor analyses. DHF cases seemed to affect all levels of society, and both men and women with similar percentage, namely $49 \%$ and $51 \%$. However, 
Table 3. The clinical characteristics of DHF cases in Purwosari District, Gunungkidul Regency, the Special Region of Yogyakarta in 2011-2017

\begin{tabular}{|c|c|c|c|c|c|c|c|c|}
\hline Clinical Characteristics & 2011 & 2012 & 2013 & 2014 & 2015 & 2016 & 2017 & Total \\
\hline \multicolumn{9}{|c|}{ Showing typical symptoms of DHF* } \\
\hline \multicolumn{9}{|l|}{ Yes } \\
\hline No & 0 & 2 & 13 & 4 & 6 & 11 & 12 & $48(78.7 \%)$ \\
\hline \multirow[t]{2}{*}{ No data } & 0 & 0 & 3 & 0 & 0 & 1 & 0 & $4(6.6 \%)$ \\
\hline & 0 & 0 & 5 & 0 & 0 & 1 & 3 & $9(14.8 \%)$ \\
\hline \multicolumn{9}{|l|}{ Status of treatment } \\
\hline Inpatient & 0 & 2 & 20 & 4 & 5 & 12 & 12 & 55 (90.2\%) \\
\hline Outpatient & 0 & 0 & 0 & 0 & 0 & 0 & 1 & $1(1.6 \%)$ \\
\hline No data & 0 & 0 & 1 & 0 & 1 & 1 & 2 & $5(8.2 \%)$ \\
\hline \multicolumn{9}{|c|}{$\begin{array}{l}\text { Length of stay at the hospital } \\
\leq 7 \text { days }\end{array}$} \\
\hline$>7$ days & 0 & 0 & 12 & 3 & 4 & 9 & 12 & 40 (65.6.\%) \\
\hline \multirow[t]{2}{*}{ No data } & 0 & 2 & 3 & 1 & 1 & 3 & 1 & $11(18.0 \%)$ \\
\hline & 0 & 0 & 6 & 0 & 1 & 1 & 2 & $10(16.4 \%)$ \\
\hline \multicolumn{9}{|c|}{$\begin{array}{l}\text { Time-lapse between the onset of fever and } \\
\text { hospitalization }\end{array}$} \\
\hline$\leq 3$ days & 0 & 1 & 7 & 3 & 1 & 0 & 7 & $19(31.1 \%)$ \\
\hline 4-7 days & 0 & 1 & 7 & 0 & 2 & 9 & 5 & $24(39.3 \%)$ \\
\hline$>7$ days & 0 & 0 & 1 & 1 & 2 & 3 & 0 & $7(11.5)$ \\
\hline Not hospitalized & 0 & 0 & 0 & 0 & 0 & 0 & 1 & $1(1.6 \%)$ \\
\hline No data & 0 & 0 & 6 & 0 & 1 & 1 & 2 & $10(16.4 \%)$ \\
\hline \multicolumn{9}{|l|}{ Diagnosis } \\
\hline DHF & 0 & 1 & 20 & 4 & 5 & 13 & 15 & 58 (95.1\%) \\
\hline DSS & 0 & 1 & 1 & 0 & 1 & 0 & 0 & $3(4.9 \%)$ \\
\hline \multicolumn{9}{|l|}{ Cases } \\
\hline Alive & 0 & 1 & 20 & 4 & 5 & 13 & 15 & $58(95.1 \%)$ \\
\hline Death & 0 & 1 & 1 & 0 & 1 & 0 & 0 & $3(4.9 \%)$ \\
\hline \multicolumn{9}{|c|}{ Same-household transmission } \\
\hline Yes & 0 & 0 & 5 & 0 & 0 & 4 & 5 & $14(23.0 \%)$ \\
\hline No & 0 & 2 & 11 & 4 & 6 & 8 & 2 & $33(54.0 \%)$ \\
\hline No data & 0 & 0 & 5 & 0 & 0 & 1 & 8 & $14(23.0 \%)$ \\
\hline \multicolumn{9}{|l|}{ Source of cases } \\
\hline Local & 0 & 2 & 15 & 3 & 4 & 8 & 6 & $38(62.3 \%)$ \\
\hline Outside & 0 & 0 & 1 & 1 & 2 & 4 & 7 & $15(24.6 \%)$ \\
\hline No data & 0 & 0 & 5 & 0 & 0 & 1 & 2 & $8(13.1 \%)$ \\
\hline
\end{tabular}

Table 4. The follow-up examinations to establish the diagnosis of dengue hemorrhagic fever in 2011-2017

\begin{tabular}{lccc}
\hline Laboratory Examinations & Positive & Negative & No data \\
& & 0 & 13 \\
\hline Decreased platelet counts & 48 & 1 & 44 \\
Anti-dengue IgG & 16 & 2 & 44 \\
Anti-dengue IgM & 15 & 1 & 59 \\
NS1 & 1 & & 59 \\
\hline
\end{tabular}


there were trends in age and occupation; both of which are intercorrelated. DHF mostly infected children (50.8\%) and students (57.4\%) (Table 2). Based on the in-depth interviews, patients' family (pediatric patients and students) reported that DHF had infected many students in one school before it spread to the other children.

Based on the in-depth interviews with patients and their families and case reports, DHF cases in Purwosari District exhibit specific clinical characteristics. More than two-thirds (78.7\%) of the patients showed typical symptoms of DHF, namely sudden high fever that lowers only with medication and is accompanied by nausea or vomiting, dizziness, headache, pain behind the eyes, muscle aches, and signs of spontaneous bleeding like nosebleeds, bleeding gums, black or bloody vomits, and black-colored feces. Almost all patients were hospitalized (90.2\%) with the most prolonged stay of $\leq 7$ days (65.6\%), and many of them consulted physicians after four to seven days from the onset of fever (39.3\%). Among the 61 cases of DHF, two infected children and one elderly patient developed Dengue Shock Syndrome (DSS), leading to one fatality (4.9\%). Not all cases in the district were locally originated because $24.6 \%$ of them were infected in other areas before returning to Purwosari. Also, $54.0 \%$ of these cases were the results of disease transmission from other DHF-infected members of the same household (Table 3).

The reports from the Gunungkidul Health Office, the district healthcare center, and patients or their families signified that only three follow-up examinations were performed to determine the diagnosis of DHF, including (1) routine blood tests to identify a decrease in platelet counts, (2) antibody tests against dengue, namely IgG and IgM, and (3) NS1 antigen assays. Unfortunately, due to inadequate reports and records of DHF cases and reliance on patients' ability to remember, only a few patients were diagnosed. The results of the follow-up examinations and corresponding diagnosis are presented in Table 4.

The combination of anamnesis, physical examinations, and follow-up examinations is essential to decide the diagnosis of DHF, and early detection is expected to prevent the development of DSS and eradicate DHF-related mortality. To achieve a good anamnesis, physicians need to ask every patient suspected of DHF about the experienced clinical characteristics of DHF because all of the official case reports and information submitted by patients and their families suggested that in $78.7 \%$ cases, the patients exhibited typical symptoms of DHF. The best but most frequently forgotten physical examination to diagnose DHF is the Rumpel-Leede test, whose positive value further confirms the diagnosis of DHF. In Indonesia, DHF examination mostly includes IgG and IgM antibody tests against DHF and NS1 antigen assays. Although these tests have high sensitivity and specificity to the diagnosis of DHF, they have several weaknesses. Both IgG and IgM antibodies are detectable by Day 5 after the onset of fever; hence, early examination tends to give a false negative result. Meanwhile, the NS1 antigen is detectable within 1 to 3 days after the onset of fever, but afterward, the assays are likely to give a false negative result. Clinics often forget one easy and straightforward examination that can be performed even in primary health services, namely the peripheral blood test. This test measures platelet and blue plasma lymphocyte counts and characterizes the morphology of erythrocytes. Blue plasma lymphocyte is a form of lymphocyte reactions to dengue infection. If it is more than or equal to $4 \%$, then its sensitivity and specificity on Day 4 are $68 \%$ and $86 \%$, while on Day 5 , they are $81 \%$ and $83 \%$, respectively (Sutaryo, 1991).

Nevertheless, not every case of DHF in Purwosari District was locally originated. As many as 15 cases came from outside of the district (Table 3). Based on the statements

Table 5. Transmigration data of DHF patients in Purwosari District in 2011-2017

\begin{tabular}{|c|c|c|c|c|c|c|c|c|}
\hline Transmigration Data & 2011 & 2012 & 2013 & 2014 & 2015 & 2016 & 2017 & Total \\
\hline \multicolumn{9}{|c|}{$\begin{array}{l}\text { Patients leaving in the last } 2 \text { weeks or when ill } \\
\text { Yes }\end{array}$} \\
\hline No & 0 & 0 & 4 & 1 & 2 & 5 & 5 & $17(27.9 \%)$ \\
\hline \multirow[t]{2}{*}{ No data } & 0 & 2 & 12 & 3 & 4 & 7 & 8 & $36(59.0 \%)$ \\
\hline & 0 & 0 & 5 & 0 & 0 & 1 & 2 & $8(13.1 \%)$ \\
\hline \multicolumn{9}{|c|}{$\begin{array}{l}\text { Patients' family leaving in the last } 2 \text { weeks } \\
\text { Yes }\end{array}$} \\
\hline No & 0 & 0 & 2 & 1 & 0 & 3 & 3 & $9(14.8 \%)$ \\
\hline \multirow[t]{2}{*}{ No data } & 0 & 2 & 14 & 3 & 6 & 9 & 10 & $44(72.1 \%)$ \\
\hline & 0 & 0 & 5 & 0 & 0 & 1 & 2 & $8(13.1)$ \\
\hline \multicolumn{9}{|c|}{$\begin{array}{l}\text { Relatives or guests staying in the last } 2 \text { weeks } \\
\text { or when patients are ill } \\
\text { Yes }\end{array}$} \\
\hline No & 0 & 0 & 1 & 0 & 1 & 3 & 1 & $6(9.8 \%)$ \\
\hline \multirow[t]{2}{*}{ No data } & 0 & 2 & 15 & 4 & 5 & 9 & 12 & $47(77.1 \%)$ \\
\hline & 0 & 0 & 5 & 0 & 0 & 1 & 2 & $8(13.1)$ \\
\hline
\end{tabular}


Table 6. The 3M-Plus behavior of the DHF patients in Purwosari District in 2011-2017

\begin{tabular}{|c|c|c|c|c|c|c|c|c|}
\hline 3M-Plus Behaviors & 2011 & 2012 & 2013 & 2014 & 2015 & 2016 & 2017 & Total \\
\hline \multicolumn{9}{|c|}{ Draining water reservoirs } \\
\hline Yes & 0 & 0 & 9 & 3 & 5 & 12 & 9 & 38 \\
\hline No & 0 & 2 & 7 & 1 & 1 & 0 & 4 & 15 \\
\hline No data & 0 & 0 & 5 & 0 & 0 & 1 & 2 & 8 \\
\hline \multicolumn{9}{|c|}{ Closing water reservoirs } \\
\hline Yes & 0 & 0 & 6 & 2 & 6 & 10 & 5 & 29 \\
\hline No & 0 & 2 & 10 & 2 & 0 & 2 & 8 & 24 \\
\hline No data & 0 & 0 & 5 & 0 & 0 & 1 & 2 & 8 \\
\hline \multicolumn{9}{|l|}{ Recycling used items } \\
\hline Yes & 0 & 0 & 3 & 4 & 6 & 4 & 1 & 18 \\
\hline No & 0 & 2 & 13 & 0 & 0 & 8 & 12 & 35 \\
\hline No data & 0 & 0 & 0 & 0 & 0 & 1 & 2 & 8 \\
\hline \multicolumn{9}{|c|}{ Sowing abate powder to water reser- } \\
\hline Yes & 0 & 1 & 12 & 0 & 4 & 8 & 9 & 34 \\
\hline No & 0 & 0 & 0 & 0 & 0 & 1 & 2 & 8 \\
\hline \multicolumn{9}{|l|}{ No data } \\
\hline \multicolumn{9}{|c|}{$\begin{array}{l}\text { Applying mosquito repellent lotion, } \\
\text { incense, spray, or electric diffuser }\end{array}$} \\
\hline Yes & 0 & 2 & 7 & 2 & 4 & 4 & 7 & 26 \\
\hline No & 0 & 0 & 9 & 2 & 2 & 8 & 6 & 27 \\
\hline No data & 0 & 0 & 0 & 0 & 0 & 1 & 2 & 8 \\
\hline \multicolumn{9}{|c|}{ Setting up mosquito nets } \\
\hline Yes & 0 & 1 & 10 & 1 & 3 & 6 & 5 & 26 \\
\hline No & 0 & 1 & 6 & 0 & 3 & 6 & 8 & 24 \\
\hline No data & 0 & 0 & 0 & 0 & 0 & 1 & 2 & 8 \\
\hline \multicolumn{9}{|c|}{$\begin{array}{l}\text { Releasing mosquito larva eaters to } \\
\text { water reservoirs }\end{array}$} \\
\hline Yes & 0 & 1 & 14 & 3 & 3 & 3 & 2 & 26 \\
\hline No & 0 & 1 & 2 & 1 & 3 & 9 & 11 & 27 \\
\hline No data & 0 & 0 & 0 & 0 & 0 & 1 & 2 & 8 \\
\hline \multicolumn{9}{|c|}{$\begin{array}{l}\text { Planting mosquito repellent plants in } \\
\text { the yard }\end{array}$} \\
\hline Yes & 0 & 0 & 0 & 4 & 1 & 0 & 1 & 6 \\
\hline No & 0 & 2 & 16 & 0 & 5 & 12 & 12 & 47 \\
\hline No data & 0 & 0 & 0 & 0 & 0 & 1 & 2 & 8 \\
\hline \multicolumn{9}{|c|}{$\begin{array}{l}\text { Improving room lighting and ventila- } \\
\text { tion }\end{array}$} \\
\hline Yes & 0 & 2 & 0 & 0 & 2 & 9 & 7 & 26 \\
\hline No & 0 & 0 & 16 & 4 & 4 & 3 & 6 & 27 \\
\hline No data & 0 & 0 & 0 & 0 & 0 & 1 & 2 & 8 \\
\hline
\end{tabular}

given by patients and their families, patients contracted DHF during their stay outside the district, and when they felt very sick, they returned home. The transmigration patterns of DHF patients (27.9) support this assertion. Furthermore, some members of the patients' family (14.8\%) left Purwosari in the last two weeks, contracted DHF, and spread the disease when they returned (14.8\%). Also, guests were staying at patients' homes in the last two weeks (9.8\%) (Table 5). This population mobility facilitates the transmission of DHF from one place to another, that is, from the center to the destination area of patients' transmigration. Higher population mobility in a region likely increases the transmission of DHF (Soegijanto, 2004).
The preventive measures against DHF are called the $3 \mathrm{M}$ Program, which consists of closing, draining, and burying potential water reservoirs. This program has been modified and upgraded to $3 \mathrm{M}$-Plus, including (1) draining water reservoirs, (2) closing any water reservoirs tightly, (3) recycling used items, (4) sowing abate powder to water reservoirs, (5) applying mosquito repellent lotion, (6) setting up mosquito nets over the bed, (7) releasing mosquito larvae eaters into water reservoirs, (8) planting mosquito repellent plants in the yard, and (9) improving room lighting and ventilation. In this study, the community behavior was assessed by first sampling the DHF-infected family members as a key factor that can be modified in preventive measures against DHF. 
The patterns of community behavior are summarized in $\mathrm{Ta}$ ble 5 .

The analysis revealed that infected patients and their families had not incorporated each item in the 3M-Plus Program into their behavior (Table 6). The $3 \mathrm{M}$-Plus is designed to prevent the occurrence of DHF early, that is, during the larval phase or breeding period of mosquitoes (Point 1, 2, 4, and 7), the presence of Aedes aegepty (Point 3, 8, and 9), and bites from dengue fever-carrier mosquitoes (Point 5 and 6). If the public implements each of these points, then the $3 \mathrm{M}$ Plus can be very useful and efficient to prevent the incidence of DHF (Centers for Disease Control and Prevention, 1998). The Office of Health Service and primary healthcare centers that are in charge of the affected areas must disseminate information about this program not only once during the occurrence of DHF but also repeatedly to transform these points into habits and ensure their continuous existence. The analysis proved that public dissemination was carried out during the case of DHF and was not followed by the actualization of the 3M-Plus behavior. For example, the communities did not sow the previously distributed abate powder because of misplaced fear and perception, which emerged from their unfamiliarity of the effects of this larvicide.

\section{Conclusion}

In Purwosari District, dengue fever tends to occur in four villages, namely Giricahyo, Girijati, Giritirto, and Giripurwo. There are two major factors of DHF outburst in this district, namely modifiable and non-modifiable factors. The modifiable factors are the environmental parameters (temperature, humidity, rainfall, elevation, surface water density) that support the life cycle of the disease vector. Based on the environmental analysis and SatScan analysis, Purwosari District provides a potential living habitat for the mosquitoes and is thereby prone to DHF endemicity.

Meanwhile, the non-modifiable factor stems from land use and the community's preventive behavior. Land use with dense vegetation is a physical factor that, in the case of Purwosari, meets the living and breeding conditions of DHF -carrier mosquitoes. The preventive behavior among the community has not been appropriately implemented, underlying the need for health workers to promote DHFpreventive habits and ensure their implementation. Relevant public dissemination has been carried out during the occurrence of DHF, but the actualization is still far from expected. Also, improving medical perception, recognizing the symptoms and warning signs of DHF, and managing DHF among the community can prevent cases of fatality due to this contagious disease.

\section{Acknowledgment}

The authors would like to thank the Office of Gunungkidul Health Service and the community health center in
Purwosari District for giving access to DHF data. Gratitude is also extended to the officers of Purwosari District and Girijati, Giriasih, Giricahyo, Giripurwo, and Giritirto Villages for granting the research permit and access during field survey of DHF. The authors would like to acknowledge the guidance and assistance of the Lecturers and Students of the Department of Environmental Geography, Faculty of Geography and Faculty of Medicine, Universitas Gadjah Mada, Yogyakarta-Indonesia.

\section{References}

Al-Ghamdi, K., Khan, M.A., and Mahyoub, J. (2009). Role of Climatic Factors in the Seasonal Abundance of Aedes Aegypti L and Dengue Fever Cases in Jeddah Province of Saudi Arabia. Curr World Environ, 4(2):307-312.

Alshehri, M.S.A. (2013). Dengue fever Outburst and its Relationship with Climatic Factors. World Applied Sciences Journal, 22(4): 506-515.

Aziz, S., Aidil, R.M., Nisfariza, M.N, Ngui, R., Lim, Y.A.L., Wan Yusoff, W.S., and Ruslan, R. (2014). Spatial Density of Aedes Distribution in Urban Areas: A Case Study of Breteau Index in Kuala Lumpur Malaysia. J Vector Borne, 51(2): 91-96.

Badan Pusat Statistik. (2017). Kecamatan Purwosari dalam Angka 2017. Yogyakarta: Badan Pusat Statistik Kabupaten Gunungkidul.

Boyce, C.K., and Lee, J.E. (2017). Plant Evolution and Climate Over Geological Timescales. Annual Review of Earth and Planetary Sciences, 45(1): 61-87.

Brunsch, A., Adji, T.N., Stoffe, D., Ikhwan, M., Oberle, P., and Nestmann, F. (2011). Hydrological Assessment of a Karst Area in Southern Java with Respect to Climate Phenomena. Indonesia: Asian Trans-Disciplinary Karst Conference Yogyakarta-INDONESIA.

Castillo, K.C, Korbl, B., Stewart, A., Gonzalez, J.F, and Ponce, F. (2011). Application of Spatial Analysis to the Examination of Dengue Fever in Guayaquil, Ecuador. Procedia Environmental Sciences, 7: 188-193.

Centers for Disease Control and Prevention. (1998). Guidelines for treatment of sexually transmitted diseases. CDC, 1:47.

Chanprasopchai, P., Pongsumpun, P., and Tang, I.M. (2017). Effect of rainfall for the dynamical transmission model of the dengue disease in Thailand. Hindawi: 1-17.

Cheong, Y.L, Leitao, P.J, and Lakes, T. (2014). Assessment of Land Use Factors Associated with Dengue Cases in Malaysia Using Boosted Regression Trees. Spatial and Spatiotemporal Epidemiology, 10: 75-84.

Chu, H., Chan, T., and Jao, F. (2013). GIS-Aided Planning of Insecticide Spraying to Control Dengue Transmission. International Journal of Health Geographics, 12(1):1-9.

Coleman, M., Coleman, M., Mabuza, A.M., Kok, G., Coetzee, M., and Durrheim, D.N. (2009). Using the SaTScan Method to Detect Local Malaria Clusters for Guiding Malaria Control Programmes. Malaria Journal, 8(68) : 1-6.

Davies, T.M., Hazelton, M.L., and Marshall, J. (2011). Sparr: Analyzing Spatial Relative Risk Using Fixed and Adaptive Kernel Density Estimation in R. Journal of Statistical Software, 39(1):1-14.

Departemen Kesehatan RI. (2018). Data dan Informasi Profil Kesehatan Indonesia. Jakarta: Kementrian Kesehatan Republik Indonesia.

Dinas Kesehatan Pemerintah Kota Yogyakarta. (2015). Profil Kesehatan Tahun 2015 Kota Yogyakarta. Yogyakarta: Dinas Kesehatan Pemerintah Kota Yogyakarta.

Dinas Kesehatan Provinsi D.I Yogyakarta. (2012). Profil Kesehatan Provinsi D.I. Yogyakarta. Yogyakarta: Dinas Kesehatan 
Provinsi D.I Yogyakarta.

Dom, N.C, Madzlan, M., Hasnan, S.N.A, and Misran, N. (2016). Water Quality Characteristics of Dengue Vectors Breeding Containers. International Journal of Mosquito Research, 3 (1): 25-29.

Duncombe, J., Clements, A., Hu, W., Weinstein, P., Ritchie, S., and Espino, F.E. (2012). Review: Geographical Information Systems for Dengue Surveillance. American Journal of Tropical Medicine, 86(5): 753-755.

Edirisinghe, G. (2017). Contribution of Rainfall Patterns for Increased Dengue Epidemic in Sri Lanka. American Scientific Research Journal for Engineering, Technology, and Sciences (ASRJETS), 35(1): 284-294.

Ehelepola, N.D.B, Ariyaratne, K., Buddhadasa, W.M.N.P., Ratnayake, S., and Wickramasinghe, M. (2015). A study of The Correlation Between Dengue and Weather in Kandy City, Sri Lanka (2003 -2012) and Lessons Learned. Infectious Diseases of Poverty, 4(1): 1-14.

Gama, Z.P, Nakagoshi, N., and Islamiyah, M. (2013). Distribution Patterns and Relationship Between Elevation and the Abundance of Aedes Aegypti in Mojokerto City 2012. Open Journal of Animal Sciences, 3(4A): 11-16.

Gomes, A.F, Nobre, A.A., and Cruz, O.G. (2012). Temporal Analysis of the Relationship Between Dengue and Meteorological Variables in The City of Rio De Janeiro, Brazil, 2001-2009. Cad Saúde Pública, 28(11): 2189-2197.

Gu, H., Leung, R.K., Jing, Q., Zhang, W., Yang, Z., Lu, J., Hao, Y., and Zhang, D. (2016). Meteorological Factors for Dengue Fever Control and Prevention in South China. Int. J. Environ. Res. Public Health, 13(9): 867.

Haryono, E and Day, M. (2004). Landform Differentiation Within the Gunungkidul Kegelkarst, Java, Indonesia. Journal of Cave and Karst Studies, 66(2): 62-69.

Haryono, E and Suratman. (2010). Significant Features of Gununngsewu Karst as Geopark Site. 4th International UNESCO Conference on Geopark Langkawi April 12-15.

HonÓrio, N.A., Silva, W.D.C., Leite, P.J., Gonçalves, J.M., Lounibos, L.P., and Oliveira, R.L.D. (2013). Dispersal of Aedes Aegypti and Aedes Albopictus (Diptera: Culicidae) in an Urban Endemic Dengue Area in The State of Rio De Janeiro, Brazil. Mem Inst Oswaldo Cruz, 98(2): 191-198.

Hugget, R.J. (2011). Fundamentals of Geomorphology $3^{\text {rd }}$ Edition. The United Kingdom: Routledge Taylor and Francis Group.

Jemal, Y and Al-Thukair, A.A. (2018). Combining GIS Application and Climatic Factors for Mosquito Control in Eastern Province, Saudi Arabia. Saudi Journal of Biological Sciences, 25(8): 1593-1602.

Kementerian Kesehatan Repbulik Indonesia. (2016). Situasi Penyakit Demam Berdarah di Indonesia Tahun 2016. Jakarta: Kementerian Kesehatan RI.

Lozano-Fuentes, S., Hayden, M.H., Welsh-Rodriguez, C., OchoaMartinez, C., Tapia-Santos, B., Konylinski, K.C., Uejio, K.U., Zielinski-Gutierrez, E., Monache, L.D., Monaghan, A.J, Steinhoff, D.F, and Eisen, L. (2012). The Dengue Virus Mosquito Vector Aedes Aegypti at High Elevation in Mexico. Am J Trop Med Hyg, 87(5): 902-909.

Moreno-Madrinan, M.J., Crosson, W.L., Eisen, L., Estes, S.M., Ester, Jr., Maurice, G., Hayden, M., Hemmings, S.N., Irwin, D.E., Lozano-Fuentes, S., Monaghan, A.J., Quattrochi, D., Welsh-Rodriguez, C.M., and Zielinski-Gutierrez, E. (2014). Correlating Remote Sensing Data with the Abundance of Pupae of The Dengue Virus Mosquito Vector, Aedes Aegypti, in Central Mexico. ISPRS Int. J. Geo-Inf, 3(2): 732749.

Ohmer, M., Liesch, T., Geoppert, N., and Goldscheider, N. (2017). On the Optimal Selection of Interpolation Methods for Groundwater Contouring: An Example of Propagation of Uncertainty Regarding Inter-Aquifer Exchange. Advance in Water Resources, 109: 121-132.
Panthwer, M.A., Pirzada, N., Abro, A., and Khahro, S.H. (2017). Spatial Risk Mapping for Dengue Fever Using GIS: A Case Study of Hyderabad. Sindh University Research Journal, 49 (1): 43-36.,

Paul, B and Tham, W.L. (2015). Interrelation Between Climate and Dengue in Malaysia. Health, 6(7): 672-678.

Rejeki, D.S.R., Fuad, A., Widartono, B.S., Murgabdarwati, E.E.H., and Kusnanto, H. (2019). Spatiotemporal Patterns of Malaria at Cross-Boundaries Area in Menoreh Hills, Java, Indonesia. Malar J, 18(80) :2-12.

Ruzman, N.S.L.N and Rahman, H.A. (2017). The Association Between Climatic Factors and Dengue Fever: A Study in Subang Jaya and Sepang Selangor. Malaysian journal of public health medicine, Special Volume (1): 140-150.

Sarfraz, M.S., Tripathi, N.K., Tipdecho, T., Thongbu, T., Kerdthong, P., and Souris, M. (2012). Analyzing the SpatioTemporal Relationship Between Dengue Vector Larval Density and Land-use Using Factor Analysis and Spatial Ring Mapping. BMC Public Health, 12(853): 1-19.

Shi, X., Miller, S., Mwenda, K., Onda, A., Rees, J., Onega, T., Gui, J., Karagas, M., Demidenko, E., and Moeschler, J. (2013). Mapping Disease at an Approximated Individual Level Using Aggregate Data: A Case Study of Mapping New Hampshire Birth Defects. Int. J. Environ. Res. Public Health, 10(9): 4161-4174.

Soegijanto S. (2004). Demam Berdarah Dengue. Surabaya: Airlangga University Press.

Sur, S., Soreghan, G.S, Yang, W., and Saller, A.H. (2010). A Record of Glacial and Milankovitch-Scale Fluctuations in Atmospheric Dust from The Pennsylvanian Tropic. Journal of Sedimentary Research, 80(12): 1046-1067.

Sutaryo. (1991). Limfosit Plasma Biru Arti Diagnostik dan Sifat Imunologik pada Infeksi Dengue. Yogyakarta: Fakultas Kedokteran Universitas Gadjah Mada.

Tiong, V., Abd-Jamil, J., Zan, M.H.A., Abu-Bakar, R.S., Ew, C.L., Jafar, F.L., Nellis, S., Fauzi, R., and Abu-Bakar, S. (2015). Evaluation of Land Cover and Prevalence of Dengue in Malaysia. Tropical Biomedicine, 32(4): 587-597.

Tsuda, Y., Takagi, M., Wang, S., Wang, Z., and Tang, L. (2001). Movement of Aedes Aegypti (Diptera: Culicidae) Released in a Small Isolated Village on Hainan Island, China. Journal of Medical Entomology, 38(1):93-98. 